\title{
UK chemists seek a greater role in policing arms ban
}

London. British chemists are mounting a last-minute appeal to the government to give academics a greater voice in the implementation of restrictions on research materials which could, in larger quantities, be used to manufacture chemical weapons.

The restrictions are included in the measures that the government is planning to adopt in order to comply with the Chemical Weapons Convention. The text of this treaty was agreed in principle in 1993, and now awaits ratification by at least 65 states before taking effect - which is widely expected to occur within the next 12 months.

As part of its implementation plans, the British government is proposing that all researchers using the chemicals listed in the proposed treaty will have to be registered with the Department of Trade and Industry (DTI), the body that will be responsible for ensuring observance of the treaty. Under certain circumstances, indeed, such research could even be banned.

Last week, during a debate in the House of Lords, the government released further details of how its licensing process will operate. In particular, Lord Fraser, minister of state at the DTI, specified that scientists who use small quantities of agents such as cholinesterase inhibitors for studies of nerve

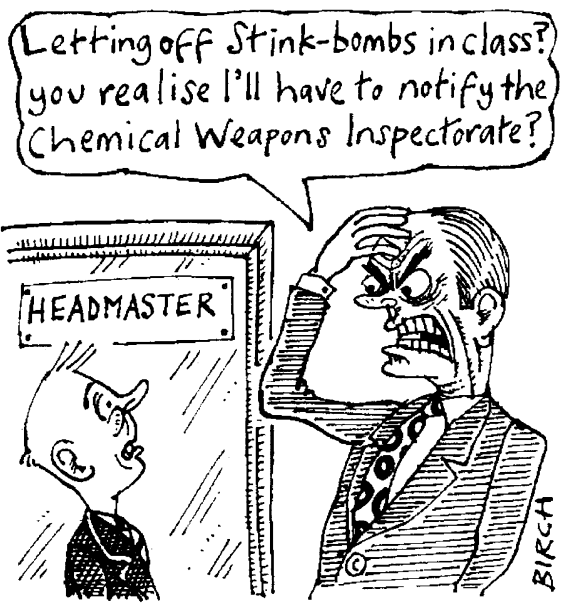

and brain function will be limited to five grams a year for a general licence.

Research chemists emphasize that they strongly support both the proposed treaty and the United Kingdom's plans to ratify it. But some are concerned that an excessively rigid application of restrictions on the use of potentially dangerous chemicals could unnecessarily impede research .

Their views were expressed by several speakers in last week's parliamentary debate. "It is vital that we rid the world of chemical weapons, but we do not want to rid the world of the science of chemistry," Lord Peston, previously professor of economics at
Queen Mary College, University of London, told the House of Lords.

One argument supported by Peston and others was that the best way of avoiding this danger would be to create a statutory advisory committee to oversee the way in which regulations are applied. Members of the committee would include individuals nominated by both the academic and industrial research communities.

"Everyone knows that the government is going to need advice on controlling potentially dangerous chemicals, and we feel strongly that it would be a good idea if the mechanism for this were to be identified in a formal way [in its bill]," says Stephen Benn, parliamentary affairs officer of the Royal Society of Chemistry (RSC). "The public interest is best served by transparency."

Benn says that the RSC is particularly concerned, for example, that despite the considerable powers to be given to the Secretary of State for Trade and Industry under the bill to regulate research, no details have yet been given of any appeals procedure for scientists whose applications to use particular chemicals are rejected.

The government has so far resisted pressure to set up such a statutory advisory group. In last week's debate, Fraser repeated previous arguments that such a committee might result in extra bureaucracy and reduce the flexibility involved in obtaining advice through non-statutory channels.

Such arguments are supported by the chemical industry, which also claims that an advisory committee could raise problems of confidentiality. "The wider information goes, the greater the risk of losing control of confidentiality," says David Culpin of the Chemicals Industry Association.

But Alistair Hay, senior lecturer in chemical pathology at the University of Leeds, warns that, without a panel of outside advisers, the government could end up listening primarily to its own chemical warfare experts and representatives of the chemical industry.

"I do not see that there is anyone [in the government's plans] who, while being sympathetic to the need to control chemicals, would say to the government: do you realize what this might mean for the academic community up and down the country," says Hay.

The proposal for an advisory committee received considerable bipartisan support during last week's debate when several of those present expressed concern that, under current plans, the task of monitoring and verifying compliance with the proposed convention would be carried out by only seven DTI officials.

David Dickson

\section{Legal action 'may end search for truth' in Canada's HIV inquiry}

Toronto. Canada's long-running inquiry into blood products contaminated with HIV and hepatitis has taken a new turn: more than 40 organizations and individuals whose activities have come under scrutiny have decided to take legal action to prevent the inquiry from concluding that there were individual cases of misconduct.

Their action follows advance warning by Mr Justice Horace Krever, head of the inquiry, that he might reach such a conclusion in his report, intended to give those likely to be named a chance to respond.

But the groups, which include the Canadian Red Cross, the federal government, pharmaceutical companies and every province except Saskatchewan, have filed suits in Canada's federal court asserting that such a course of action is beyond the inquiry's mandate.

The lawsuits have attracted criticism from organizations representing individuals affected by transfusions of infected blood. The president of the Canadian Haemophilia Society, for example, claims that, if the suits are upheld, the truth will never be known about why more than 1,200 haemophiliacs and transfusion recipients contracted HIV between 1980 and 1985 .

The Canadian Red Cross in particular faces more than 70 allegations against senior officials. The charges include failing to take basic measures to exclude people in highrisk groups from donating blood, as well as continuing to distribute blood products that had not been heat-treated when it had a substantial inventory of such products.

Among those named is George Weber, the secretary-general of the International Federation of Red Cross and Red Crescent Societies. Weber was head of the Red Cross in Canada between 1983 and 1993, and is alleged to have failed adequately to "oversee, direct and provide resources" for blood transfusion and donor recruitment services.

But in an affidavit aimed at preventing Krever from making such charges part of his report, Weber says the notice of potential findings "could seriously damage my career and future employment prospects". The groups taking legal action also argue that Judge Krever's actions will expose them to claims for compensation from those who contracted HIV or hepatitis C after transfusions with infected blood.

The report of the Krever commission is due to be published by the end of September, but seems certain to be delayed by the legal action. Last Friday, 2 February, consumer groups opposed to the lawsuits were given the right to participate in hearings on the suit, due to take place in May.

David Spurgeon 